\title{
Technological-Technical and Environmental Evaluation of Herbaceous Plant Usage for the Production and Burning of Granulated Biofuel
}

\author{
Dionizas Streikus ${ }^{1}$, Algirdas Jasinskas ${ }^{1 *}$, Egidijus Šarauskis ${ }^{1}$, \\ Kęstutis Romaneckas ${ }^{2}$, Marek Marks ${ }^{3}$ \\ ${ }^{1}$ Institute of Agricultural Engineering and Safety, Aleksandras Stulginskis University, Kaunas, Lithuania \\ ${ }^{2}$ Institute of Agroecosystems and Soil Science, Aleksandras Stulginskis University, Kaunas, Lithuania \\ ${ }^{3}$ Department of Agroecosystems, University of Warmia and Mazury in Olsztyn, Poland
}

Received: 16 July 2018

Accepted: 21 October 2018

\begin{abstract}
Three unconventional herbaceous energy plants - sida (Sida hermaphrodita Rusby), elephant grass (Miscanthus giganteus) and reed canary grass (Phalaris arundinacea) - were grown and investigated in the experimental fields of Aleksandras Stulginskis University, and the technical means of plant preparation and usage for energy purposes were investigated. The physical-mechanical characteristics (moisture content, density, flow angles) of chopped and milled unconventional energy plants were investigated. These characteristics are required to project and choose the supply, transportation and storage equipment. In evaluating the quality of plant chopping and milling, the fractional compositions of reed canary grass, sida and elephant grass chaff as well as the mill were determined. The largest chaff fraction was found in a sieve with $8-\mathrm{mm}$ diameter holes (from 52.0 to $62.7 \%$ ), and the largest mill fraction was found in a sieve with 0.5 - and $0.63-\mathrm{mm}$ diameter holes (from 37.6 to $46.4 \%$ ). The pellet moisture content was sufficiently low and varied from $6.7 \%$ to $9.6 \%$. The highest density was determined in reed canary grass pellets $\left(1035.1 \pm 63.9 \mathrm{~kg} \mathrm{~m}^{-3} \mathrm{DM}\right)$, and the lowest density was in elephant grass pellets $\left(653.6 \pm 67.1 \mathrm{~kg} \mathrm{~m}^{-3} \mathrm{DM}\right)$. The emission of harmful gases was determined when various unconventional energy plants were burned. The highest concentration of carbon monoxide (CO) was observed when burning elephant grass (2294.7 ppm), and the smallest concentration of CO was observed when burning reed canary grass $(905.2 \mathrm{ppm})$. The most carbon dioxide was detected when burning sida $(7.9 \%)$, and the smallest when burning elephant grass (5.2\%). The nitrogen oxide emissions differed only insignificantly; the values ranged from $176.2 \mathrm{ppm}$ (Reed canary grass) to $216.1 \mathrm{ppm}$ (Elephant grass). The production of granules, when biomass was not dried artificially in a dryer, was calculated to have
\end{abstract}

*e-mail:algirdas.jasinskas@asu.lt 
a prime cost of $0.12 \mathrm{EUR} / \mathrm{kg}$. When energetic grasses were dried using dispergation, the primary cost increases to $0.13 \mathrm{EUR} / \mathrm{kg}$.

Keywords: herbaceous plants, biofuel, chopping, milling, granulation, pellet properties, harmful emissions

\section{Introduction}

The potential for using solar, wind and water energy is limited in many European countries, and the extraction of energy from plant biomass is the most perspective sort of alternative energy. In evaluating new energetic plants, special attention should be paid to plants with high energetic value, high productivity and adaptability to local soil and climatic conditions. Perennial energy crops have high productivity and biomass has a high calorific value to produce a considerable amount of energy from 1 ha and high energy-biomass production ratio [1].

Also, there are obligations to the Europe Union that until 2020 the amount of biomass should reach $23 \%$ in total energy balance in Lithuania [2]. Biomass accounts for $90 \%$ of all renewable energy in Lithuania [3].

Some sorts of reed plants used for preparation of forage are suitable for energetic needs, including Phalaris arundinacea and Festuca arundinacea. At the Institute of Agricultural Engineering and Safety at Aleksandras Stulginskis University and its affiliates, several prospective coarse grasses are grown and investigated, e.g., elephant grass, or sida, which yields bigger harvests in countries with warm climates. Sida also grows rather well in Lithuanian climatic conditions, but the deeper analysis and research into the evaluation of technologies and techniques of plant preparation, processing and usage for energetic needs in Lithuania have not been reported. Thus, to adopt new plant biomass sources of renewable energy, further research and the creation of new technologies are needed.

In many European countries, reed canary grass (Phalaris arundinacea), switchgrass (Panicum virgatum) and elephant grass (Miscanthus spp.) are popular [4, 5]. For these plants, the same technologies and techniques are suitable, for both forage grass and straw, to collect traditional grass plant biomass and prepare biofuel. For biofuel as well as for forage production, the first technological operation is to cut grass, and later it needs to be dried to $17-20 \%$ moisture content, pressed into rolls or rectangular packets and must be stored in a covered repository. These procedures must be done to make fuel more convenient for transportation and storage, as well as using this prepared biofuel for combustion in the boilers, and it must ensure an efficient and consistent combustion process [5].

Elephant grass (genus Miscanthus) is a perennial grass plant of the Poaceae family, with glossy bending leaves that typically grow to $2.5-3 \mathrm{~m}$ and can reach 4-6 $\mathrm{m}$. The stem can measure up to $60 \mathrm{~mm}$ thick
$[6,7]$. This plant is also known as Chinese cane [7]. Some Miscanthus species are the most valued, which in a short period can grow a large amount of biomass, which is evaluated in tons per hectare: Miscanthus giganteus, Miscanthus sinensis, Miscanthus floridulus and Miscanthus sacchartiflorus. Elephant grass grows naturally in Africa and in the subtropics and tropics of South Asia, as well as in the Eastern Asian average climate zone from Oceania to the Japanese Mountains and Himalayas [8].

The ideal conditions for growth of elephant grass are during a vegetation period with 700-900 mm precipitation distributed evenly across the entire vegetation period. If there are dry periods during the vegetation period, growth stops and leaves begin to fall. The average temperature should be above $7^{\circ} \mathrm{C}$, and the ideal temperature is $8.5^{\circ} \mathrm{C}$. During the first year of growth, up to $90 \%$ of plants may freeze; in further growth years, the negative effect of cold is not observed [9].

During colder winters, the first-year crop may grow sparsely or even disappear. Research results of British scientists show that one limiting factor for the elephant grass plants is water. It was calculated that it needs approximately $250 \mathrm{~mm}$ precipitation for $10 \mathrm{t} \mathrm{ha}^{-1} \mathrm{DM}$ (dry mass) harvest. Based on these data, it is possible to forecast that there are favourable conditions in Lithuania for the growth of elephant grass, at least according to precipitation levels. [10].

As an energetic plant, elephant grass may be grown for fuel in the same area for approximately 25 years. Usually, during the third year, plants grow to approximately $3 \mathrm{~m}$ high and may give a good harvest. The harvest of elephant grass biomass depends on soil moisture, and thus crop watering will give a harvest surplus in almost every year [11]. With favourable growth conditions and sufficient soil moisture, elephant grass may grow up to $25 \mathrm{t} \mathrm{ha}^{-1}$ of dry material. In addition, grass may accumulate $10-20 \mathrm{t} \mathrm{ha}^{-1}$ of rhizome mass. As the plant harvest mass increases, additional $\mathrm{CO}_{2}$ is taken from the atmosphere by the plants. Thus, these plants reduce atmospheric carbon dioxide to mitigate greenhouse effects. Elephant grass biomass is caloric: $1 \mathrm{~kg}$ of dry biomass provides approximately $17 \mathrm{MJ}$ of energy.

Biomass should be harvested when moisture does not exceed 20\%. This moisture content can be reached in February, March or April. Plants should be cut to a height of 100 to $150 \mathrm{~mm}$ to secure suitable plant collection. A widely used method of harvest collection of energetic plants is pressing. Rolls or rectangular packets may be pressed [12]. 


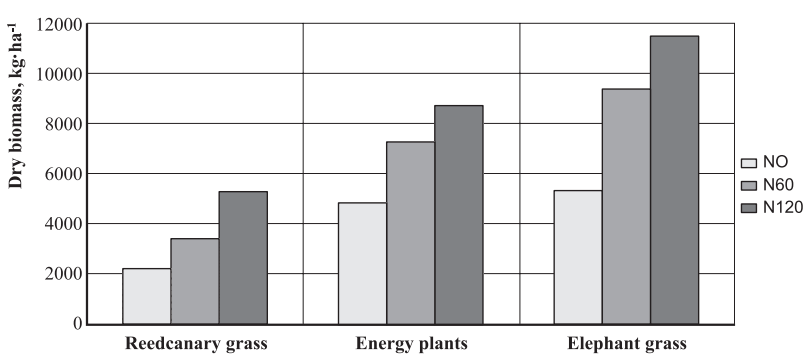

Fig. 1. Influence of additional fertilisation on quantity of dry biomass [14].

Chopped mass with suitable moisture content can instantly be used to heat stoves. In addition, elephant grass may be used as a raw material in biogas power plants [13].

Sida is another prospective plant for use in the energy sector. Sakhalin, Japanese and hybrid sida is used for energetic needs (Sida hermaphrodita). Sida may grow quite well in places with only 500-600 mm of precipitation. Sida may reach a height of 3-4 metres and propagates itself with seeds. However, propagation through the roots (as with elephant grass) is also possible. A sida harvest may range from 8 to $20 \mathrm{t} \mathrm{ha}^{-1}$ of dry material in a given year. Similar to elephant grass, the sida harvest may depend on soil and climatic conditions [14].

According to research performed in Lithuania, additional fertilisation greatly influences the quantity of dry mass, as in Fig. 1 [14].

Fertilising plantations of Phalaris arundinacea with additional nitric fertilisers $\left(100 \mathrm{~kg} \mathrm{ha}^{-1}\right)$ increased the quantity of dry biomass $52 \%$; by increasing the fertilisers to $200 \mathrm{~kg} \mathrm{ha}^{-1}$, the quantity of dry biomass increased 2.4-fold. A similar tendency to increase dry mass was observed when plantations of sida and elephant grass were fertilised.

The caloric value of sida is similar to that of fairtree and pine (approximately $18.7 \mathrm{MJ} / \mathrm{kg} \mathrm{DM}$ ). However, taking into consideration the speed of sida growth, in one year sida may give a one-hectare harvest that is two-fold greater than fair-tree [15].

The aim of this work is to evaluate technologicaltechnical solutions for preparation, processing and usage of unconventional energy plants - perennial grass (reed canary grass) and coarse grasses (elephant grass, sida) - for production of pressed biofuel to justify their use for energy purposes and evaluate their impact on the environment.

\section{Materials and Methods}

\section{Investigated Plants}

Three herbaceous energy plants were investigated: sida (Sida hermaphrodita Rusby), elephant grass (Miscanthus giganteus) and reed canary grass (Phalaris arundinacea). These plants were grown in the experimental fields of the Lithuanian Research Centre for Agriculture and Forestry, and the technical means of preparing these plants and using them for energy purposes were investigated at Aleksandras Stulginskis University. Techniques for plant chopping, milling and pelleting were investigated.

\section{Chopping and Milling Quality}

For the preparation of biofuel from herbaceous energy plants, chopping and milling quality of these plants should satisfy the requirements for the combustion chamber, chopped mass transportation machinery and storage. For the first step of stem chopping we used a drum chopper in a Maral 125 forage harvester [11]. Before the production of biofuel pellets, the prepared chaff should be chopped to the form of the mill. A Retsch SM 200 mill was used for the chaff milling,

The milling quality was determined using a standard methodology (DD CEN/TS 15149-1:2006). The fractional composition of the chopped plants was determined using a set of $200-\mathrm{mm}$ diameter sieves with round holes of diameters $0 \mathrm{~mm}, 0.25 \mathrm{~mm}, 05 \mathrm{~mm}$, $0.63 \mathrm{~mm}, 1.0 \mathrm{~mm}$ and $2.0 \mathrm{~mm}$. The mass remaining in the sieves was weighed, and the sample fraction percentages were calculated [16]. Each test was repeated five times.

\section{Pellet Production}

Pellets have improved properties compared to non-processed biomass. The particular advantage is increased density, when better control of combustion process could be achieved. Also, emissions of pollutants during combustion of pellets are expected to be lower [17].

For pellet production, the milled herbaceous energy plants were granulated in a small-capacity (100 $\mathrm{t} \mathrm{ha}^{-1}-120 \mathrm{~kg} \mathrm{~h}^{-1}$ ) granulator with a horizontal granulator matrix. The diameter of the pellets was $6 \mathrm{~mm}$ [18]. The mill was granulated in the traditional way: before the mill entered the granulator, the mill was mixed thoroughly to achieve homogeneity. Next, the raw material was moistened, and the dosage unit was supplied to the press chamber, where the mill was moved by rollers through the matrix holes $(6-\mathrm{mm}$ diameter). The biomass was pressed through holes to form pellets. When the pellets were cooled, their biometric parameters (dimensions, humidity, volume and density) were evaluated.

\section{Determining Pellet Parameters and Physical-Mechanical Properties}

The pellet parameters were determined by measuring their height and diameter (accurate to $0.05 \mathrm{~mm}$ ). Experimental trials of 10 pellets were randomly selected from each plant species. 
Pellet weight was assessed using KERN ABJ scales (accurate to $0.001 \mathrm{~g}$ ). The weights were calculated for each type of plant using 10 granules and the mean errors were calculated.

Pellet moisture content was determined in a laboratory drying chamber oven according to the standard method (CEN/TC 14774-1:2005). Pellet volume was calculated using pellet size (diameter and length) [19].

Pellet filled density and flow angles. Granule filled density is determined by filling a cylindrical vessel of $1 \mathrm{dm}^{3}$ with granules (the vessel was weighed before filling). The vessel was filled freely with granules to the upper edge without pressing. By subtracting the mass of the empty vessel, we calculated the mass of granules and their density (chopped mass $(\mathrm{g})$ is divided from volume of cylindrical vessel $\left(\mathrm{m}^{-3}\right)$ ) [20]. The test was performed three times. The granule mass for the dry materials was also calculated.

Fall and natural slope angles are needed to project equipment needs for transportation of chopped straw to fireplaces and depositories [20]. These are determined using a stand. The rectangular vessel was transparent and made of organic glass. The vessel was filled with $10 \mathrm{~kg}$ of granules; a damper was opened and the granules were allowed to fall naturally. A ruler was turned and angles were measured with a protractor. The test was repeated five times and the average meanings and errors of the angles were calculated.

\section{Pellet Burning and Impact on the Environment}

The limit values of emitted pollutants from fuelburning devices are regulated by the norms of emitted pollutants from fuel-burning devices as confirmed by the Minister of the Environment of the Republic of Lithuania (LAND 43-2013). The norms regulate the limit values of the pollutants from the burned fuel, including grass plants and straw. The limit values of the emitted pollutants from newly burned biofuel and the present devices led to a caloric productivity of 0.12-1.0 MW (with standard $\mathrm{O}_{2}=6 \%$ for volume concentration percentage) [21].

In boilers heated with solid biofuel, the fuel burning and concentration of emitted pollutants depends on the type of fuel, its quality and its form. These fuel parameters are very important when making projections for new fuel-supply burning devices. To investigate the influence of these parameters on pollutant formation, a search of the analysis in a low-power $(5 \mathrm{~kW})$ solid fuel boiler was performed. The boiler was meant for burning bulk fraction fuel such as logs, briquettes and granules. The research was performed at the Lithuanian Energy Institute in the research laboratory and tests of caloric equipment. Pollutants gathered during burning were measured using product analysers: a Datatest 400CEM and analyser VE7. The total quantities of carbon, hydrogen, nitrogen, sulphur and oxygen were

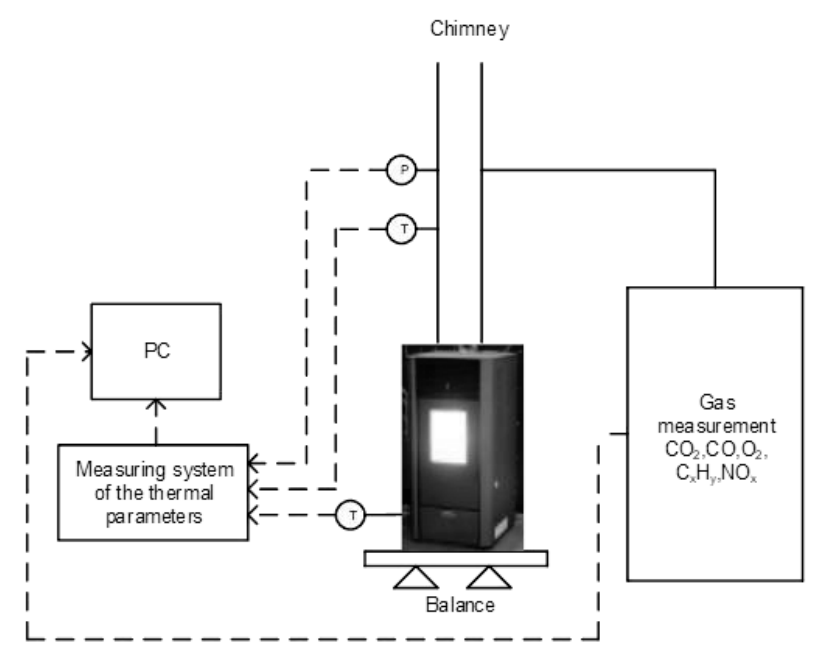

Fig. 2. Scheme of determination of granule burning and emissions.

determined in a device (No. 8B/3) according to the requirements of the standard 15104:2010 [16]. The scheme for granule burning and emission determination is presented in Fig. 2.

Harmful emissions to the environment were determined and compared for burning of granulated biofuels of various sorts from unconventional grass plants: elephant grass, sida and reed canary grass. Samples of chopped plant stems (10 kg each) were supplied to the research laboratory for burning and emission research. The burning period for each sample was 8-10 min.

Analysis of the research result variance was performed for three replications by employing the $\mathrm{F}$ test and LSD (95\% probability level) to assess significance.

\section{Results and Discussion}

\section{Determining Plant Chaff and Mill Physical-Mechanical Properties}

Having performed the experimental research, the physical-mechanical properties of mill and chaff were determined for the unconventional grassy plants chopped by drum chopper and hammer mill, including elephant grass, sida and reed canary grass; the properties were moisture content, density and flow angles. These properties are needed for projecting and selecting supply-transportation and storage devices.

The physical-mechanical properties of stems chopped by the drum chopper were determined, including moisture content, density and natural slope and fall angles (Table 1).

Table 1 shows that the filled density of the stem chaff of elephant grass chopped using a drum chopper in the Maral 125 forage chopper was smallest $\left(41.6 \mathrm{~kg} \mathrm{~m}^{-3}\right.$ $\mathrm{DM})$, and that of reed canary grass was twice as large (75.7 $\left.\mathrm{kg} \mathrm{m}^{-3} \mathrm{DM}\right)$. 
Table 1. Physical-mechanical properties of energy plant chaff.

\begin{tabular}{|c|c|c|c|c|c|c|}
\hline \multirow{2}{*}{ Plant sort } & \multirow{2}{*}{$\begin{array}{c}\text { Chaff moisture } \\
\text { content, } \\
\%\end{array}$} & \multicolumn{3}{|c|}{ Chaff parameters } & \multicolumn{2}{c|}{ Flow angles } \\
\cline { 3 - 7 } & & $\begin{array}{c}\text { Mass, } \\
\mathrm{g}\end{array}$ & Volume, $\mathrm{m}^{3}$ & $\begin{array}{c}\text { Filled density, } \\
\mathrm{kg} \mathrm{m}^{-3}\end{array}$ & $\begin{array}{c}\text { Natural slope } \\
\text { angle } \alpha_{n} \text {, degrees }\end{array}$ & $\begin{array}{c}\text { Fall angle } \\
\alpha_{g r}, \text { degrees }\end{array}$ \\
\hline Elephant grass & $14.9 \pm 1.3$ & $586.2 \pm 28.5$ & 0.012 & $\begin{array}{c}48.9 \pm 2.3 \\
(41.6 \mathrm{DM})\end{array}$ & $44.2 \pm 1.3$ & $73.3 \pm 1.8$ \\
\hline Sida & $14.1 \pm 0.3$ & $891.4 \pm 33.2$ & 0.011 & $\begin{array}{c}81.0 \pm 4.8 \\
(69.6 \mathrm{DM})\end{array}$ & $42.8 \pm 2.8$ & $74.0 \pm 3.0$ \\
\hline Reed canary grass & $14.7 \pm 0.9$ & $975.7 \pm 25.8$ & 0.011 & $\begin{array}{c}88.7 \pm 3.5 \\
(75.7 \mathrm{DM})\end{array}$ & $43.5 \pm 2.9$ & $79.8 \pm 3.1$ \\
\hline
\end{tabular}

The natural slope angles $\alpha_{n}$ for all three plants are very similar and differed in the limits of 42.8-44.2 degrees. The differences in fall angles $\alpha_{g r}$ were more significant, ranging from 73.3 degrees (elephant grass) to 79.8 degrees (reed canary grass).

Fractional composition of the mass chopped in a drum chopper was determined by applying the European Union methodology, in which sieves with holes of various diameters were used. The mass remaining in the sieves was weighed, and the fraction of sample was calculated as a percentage.

We determined that the biggest fraction of elephant grass chaff accumulated in the sieve with $8-\mathrm{mm}$ diameter holes, at $62.7 \pm 23.2 \%$; the quantity of dust was $0.2 \pm 0.1 \%$. Fractions of chopped sida were evenly distributed in the sieves; a bigger fraction of sida chaff accumulated in the sieve with round holes of $8 \mathrm{~mm}$ diameter, at $61.6 \pm 2.3 \%$; the quantity of dust was $4.7 \pm 0.4 \%$. The length of chopped reed canary grass changed in the range of 16.2-22.4 mm; on average, the length was $19.3 \mathrm{~mm}$. The length of particles of reed canary grass chaff was measured using sliding callipers (precision $0.1 \mathrm{~mm}$ ) because it was difficult to evaluate the fractional composition of chaff in the sieves. This grassy plant has small stems, and it is hard to separate these fractions using sieves.

The prepared chaff was used to produce the granules and must be milled using a Hammer mill Retsch SM 200. The researched physical-mechanical properties of the stem mill are presented in Table 2.

Comparing the density of plant chaff, there was relatively less filled density of elephant grass, at $111.0 \mathrm{~kg} \mathrm{~m}^{-3} \mathrm{DM}$. As seen from the data presented in Table 2, the filled density of elephant grass mill was the smallest, and the density of sida was twice as high (224.5 $\left.\mathrm{kg} \mathrm{m}^{-3} \mathrm{DM}\right)$.

The natural slope angles $\alpha_{n}$ of all researched plants were very similar, ranging from 38.9 to 39.8 degrees. The variation in diapason (range) of the fall angles $\alpha_{g r}$ was larger, from 62.5 degrees (elephant grass) to 75.8 degrees (reed canary grass).

Table 2. Physical-mechanical properties of the energy plant mill.

\begin{tabular}{|c|c|c|c|c|c|c|}
\hline \multirow{2}{*}{ Plant sort } & \multirow{2}{*}{$\begin{array}{c}\text { Mill moisture } \\
\text { content, } \\
\%\end{array}$} & \multicolumn{3}{|c|}{ Mill parameters } & \multicolumn{2}{c|}{ Flow angles } \\
\cline { 5 - 7 } & & $\begin{array}{c}\text { Mass, } \\
\mathrm{g}\end{array}$ & Volume, $\mathrm{m}^{3}$ & $\begin{array}{c}\text { Filled density, } \\
\mathrm{kg} \mathrm{m} \mathrm{m}^{-3}\end{array}$ & $\begin{array}{c}\text { Natural slope } \\
\text { angle } \alpha_{n} \text {, degrees }\end{array}$ & $\begin{array}{c}\text { Fall angle } \\
\alpha_{g}, \text { degrees }\end{array}$ \\
\hline Elephant grass & $7.1 \pm 0.2$ & $369.4 \pm 5.7$ & 0.0033 & $\begin{array}{c}119.5 \pm 4.3 \\
(111.0 \mathrm{DM})\end{array}$ & $39.8 \pm 1.5$ & $62.5 \pm 1.5$ \\
\hline Sida & $5.9 \pm 0.6$ & $262.5 \pm 6.7$ & 0.0011 & $\begin{array}{c}238.6 \pm 4.1 \\
(224.5 \mathrm{DM})\end{array}$ & $39.6 \pm 2.4$ & $69.8 \pm 2.4$ \\
\hline Reed canary grass & $6.0 \pm 0.3$ & $246.3 \pm 5.9$ & 0.0011 & $\begin{array}{c}223.9 \pm 16.3 \\
(214.9 \mathrm{DM})\end{array}$ & $38.9 \pm 2.1$ & $75.8 \pm 2.0$ \\
\hline
\end{tabular}

Table 3. Herbal energy plant-pellet physical properties.

\begin{tabular}{|c|c|c|c|c|}
\hline \multirow{2}{*}{ Plant sort } & Pellet moisture content, & \multicolumn{3}{|c|}{ Pellet parameters } \\
\cline { 3 - 5 } & $\%$ & Mass, g & Volume, $\mathrm{m}^{3}$ & ${\text { Density, } \mathrm{kg} \mathrm{m} \mathrm{m}^{-3}}^{7}$ \\
\hline Elephant grass & 8.4 & 0.57 & $7.96 \cdot 10^{-6}$ & $\begin{array}{c}713.5 \pm 67.1 \\
(653.6 \pm 67.1 \mathrm{DM})\end{array}$ \\
\hline Sida & 9.6 & 0.74 & $7.01 \cdot 10^{-6}$ & $\begin{array}{c}1072.3 \pm 43.4 \\
(969.3 \pm 52.6 \mathrm{DM})\end{array}$ \\
\hline Reed canary grass & 6.7 & 0.85 & $7.36 \cdot 10-6$ & $\begin{array}{c}1109.9 \pm 31.6 \\
(1035.1 \pm 63.9 \mathrm{DM})\end{array}$ \\
\hline
\end{tabular}


The quality of chopping was determined analogously: when plants were chopped using a drum chopper, the fractional composition of their mass was determined using sieves with holes of various diameters. Having evaluated the dependency of the plant mill fractional part (\%) from the hole diameter $(\mathrm{mm})$, we determined that the largest fraction of elephant grass accumulated in the sieves with $0.63-\mathrm{mm}$ diameter holes $(46.4 \pm 0.6 \%)$; a slightly smaller fraction accumulated in the sieve with 2-mm diameter holes $(31.0 \pm 0.0 \%)$. The largest fraction of sida accumulated in the sieves with $0.5-\mathrm{mm}$ diameter holes $(45.9 \pm 3.5 \%)$; and a large mill fraction accumulated in the sieves with 1 -mm diameter holes $(31.0 \pm 2.2 \%)$. Having evaluated the fractional composition in the mill for reed canary grass, we determined that the size of $70.7 \%$ of the particles was smaller than $1 \mathrm{~mm}$. The fractional composition of the milled particles was relatively even. The largest fraction of reed canary grass accumulated in the sieve with 1 -mm diameter holes $(28.34 \pm 4.2 \%)$, and the smallest in the sieve with $2-\mathrm{mm}$ diameter holes $(1.0 \pm 0.1 \%)$. The dust was $13.4 \pm 1.2 \%$ of the total mill mass.

In evaluating the quality of chopping and milling of unconventional energy plants, the fractional composition of the chaff and mill of elephant grass, sida and reed canary grass in sieves was determined with various diameter holes. The largest fraction accumulated in the sieve with 8 -mm diameter holes (61.6 to $62.7 \%$ ), and the largest mill fraction was from elephant grass in the sieve with $0.63-\mathrm{mm}$ diameter holes $(46.4 \%)$.

\section{Determination of Pellet Properties}

In further experiments, the prepared mill of energy plants was pressed into pellets, and the pellets' physical properties, elemental composition, caloric value, ash content and harmful emissions were determined.

The moisture content and mass of the pellets were determined, and the pellet volume, density and dry matter content were calculated. The results of the computed values are presented in Table 3 .

From the data in Table 3, the pellet moisture content was sufficiently low and varied from $6.7 \%$ to $9.6 \%$. The highest density was detected in the reed canary grass pellets $\left(1035.1 \pm 63.9 \mathrm{~kg} \mathrm{~m}^{-3} \mathrm{DM}\right)$, with smaller variation in sida pellet density $\left(969.3 \pm 52.6 \mathrm{~kg} \mathrm{~m}^{-3} \mathrm{DM}\right)$. The lowest density was measured in elephant grass pellets (653.6 $\left.\pm 67.1 \mathrm{~kg} \mathrm{~m}^{-3} \mathrm{DM}\right)$.

\section{Evaluation of the Impact of Burning Biofuel Pellets on the Environment}

When burning granules made of unconventional energy plants, the smoke temperature was fixed, and the emissions of harmful pollutants were determined, including carbon dioxide $\mathrm{CO}_{2}$, carbon monoxide $\mathrm{CO}$, sulphur dioxide $\mathrm{SO}_{2}$, nitrogen oxide $\mathrm{NO}_{x}$ and unburned hydrocarbons $\mathrm{C}_{\mathrm{x}} \mathrm{H}_{\mathrm{y}}$. These research results are presented in Figs 3-5.
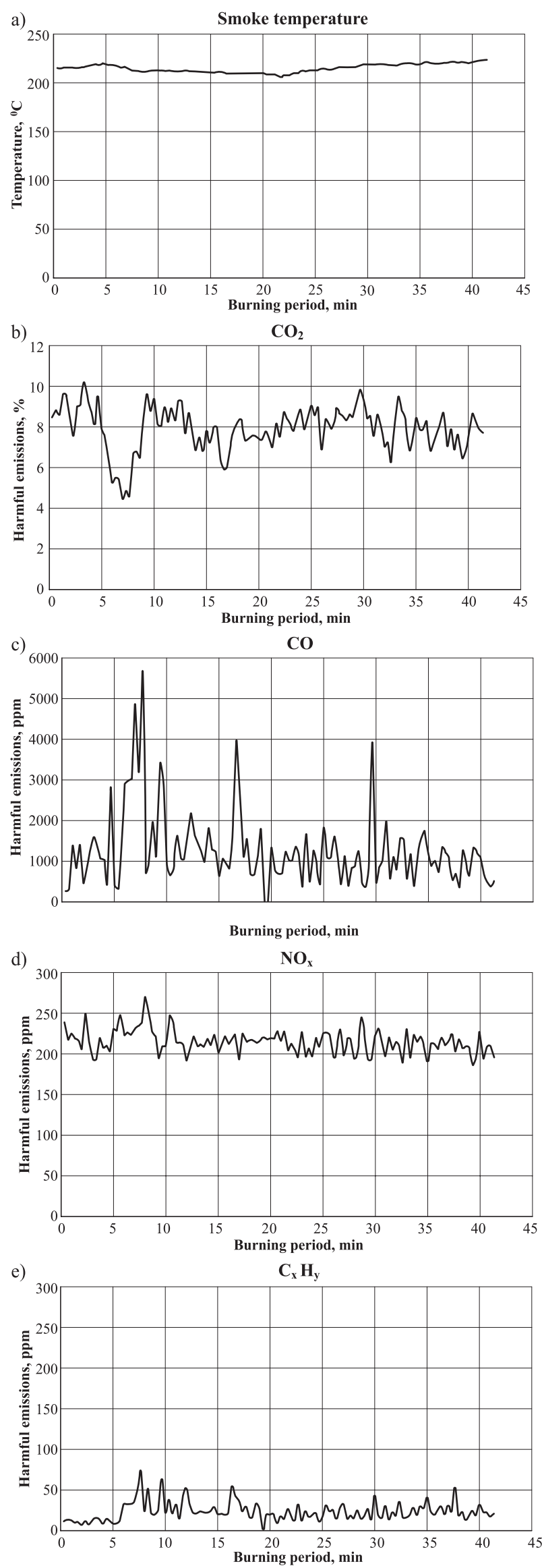

Fig. 3. Harmful emissions when burning sida granules: a) smoke temperature; b) carbon dioxide; c) carbon monoxide; d) nitrogen oxides; and e) hydrocarbons. 


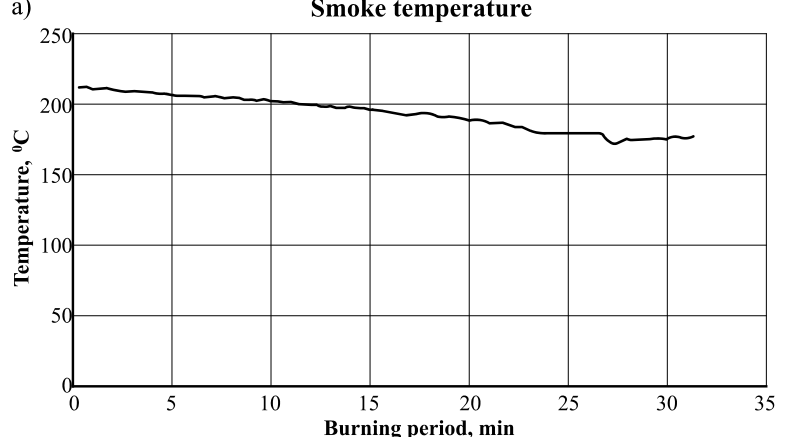

b)

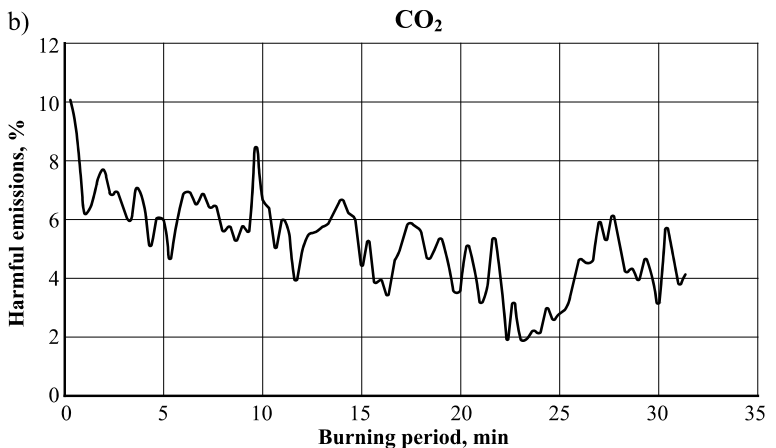

c)

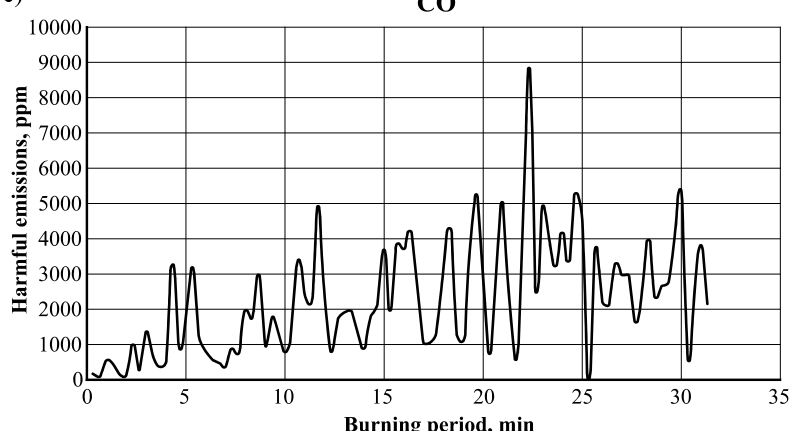

d)

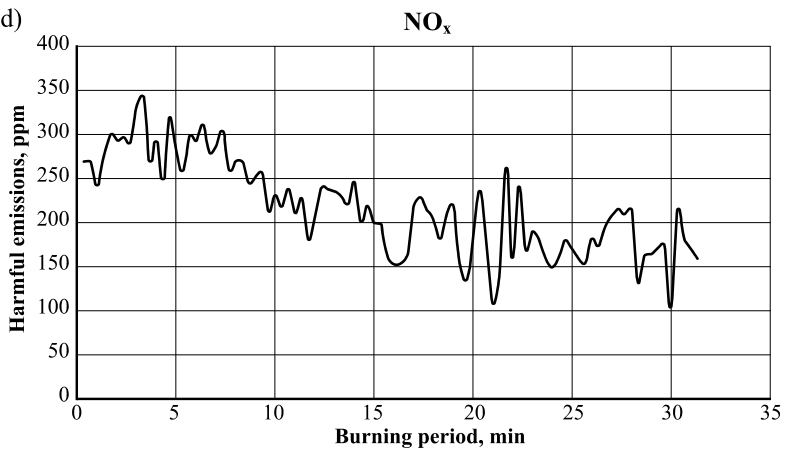

e)

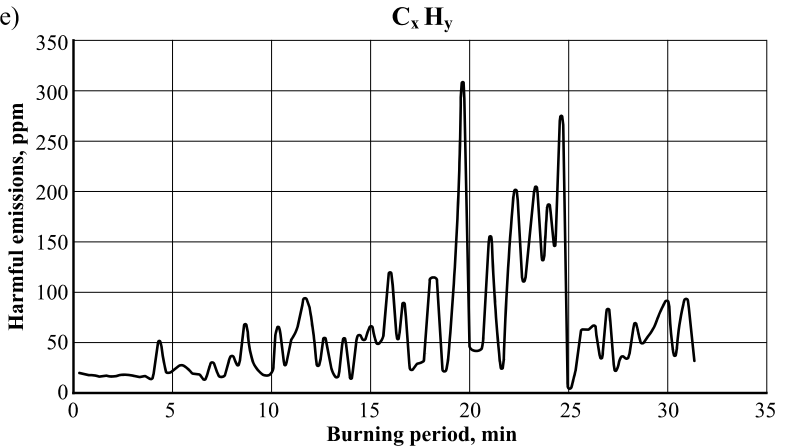

Fig. 4. Harmful emissions when burning elephant grass granules: a) smoke temperature; b) carbon dioxide; c) carbon monoxide; d) nitrogen oxides; e) hydrocarbons.
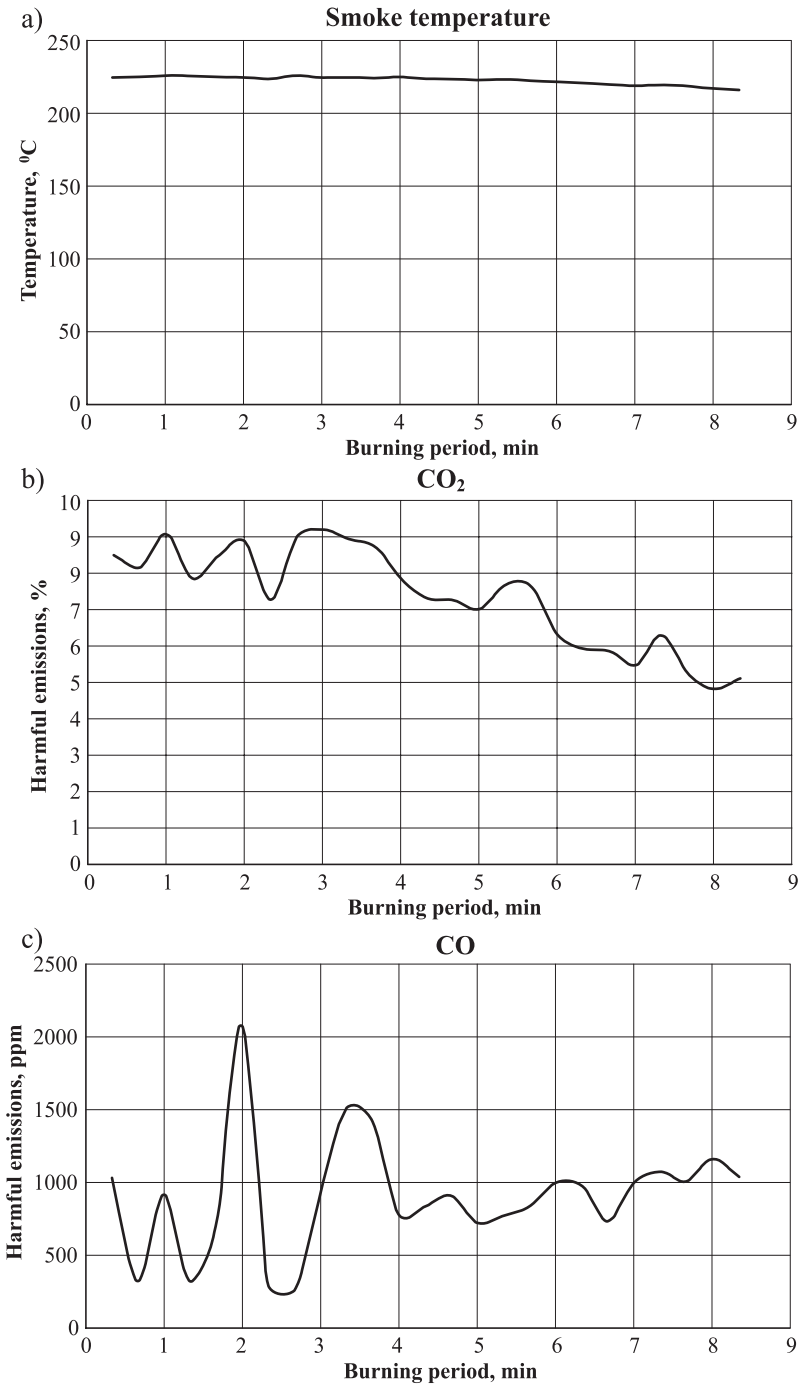

d) NO

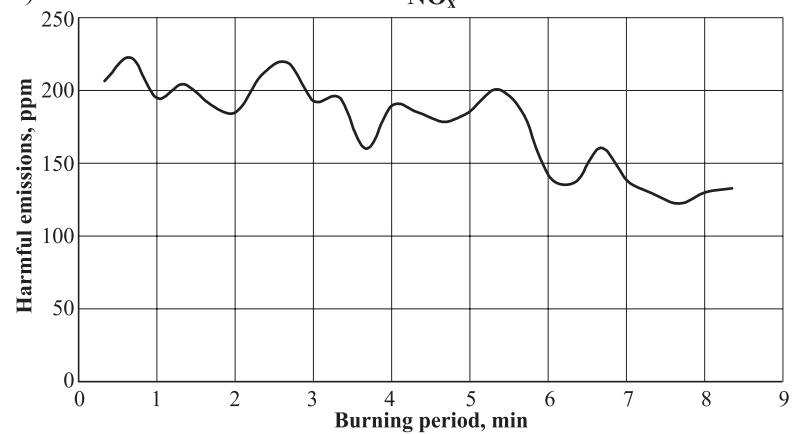

e)

$\mathrm{C}_{\mathrm{x}} \mathrm{H}_{\mathrm{y}}$

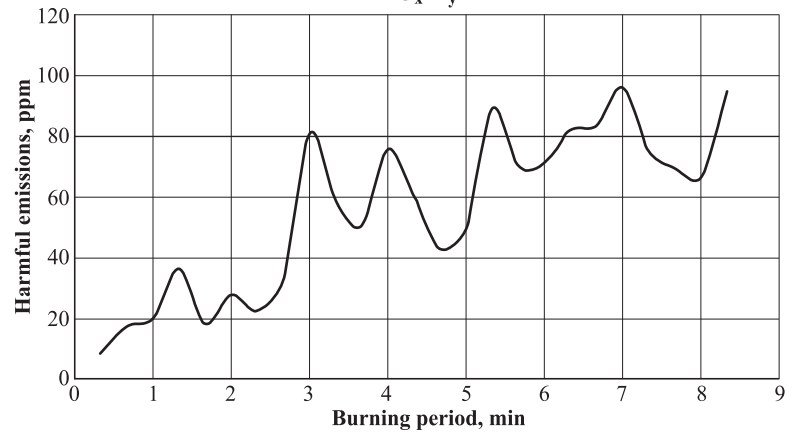

Fig. 5. Harmful emissions when burning reed canary grass granules: a) smoke temperature; b) carbon dioxide; c) carbon monoxide; d) nitrogen oxides; and e) hydrocarbons. 
Table 4. Research results of harmful emissions from burning granules of unconventional herbaceous energy plants (average values).

\begin{tabular}{|c|c|c|c|c|c|c|}
\hline Species of energy plant & $\begin{array}{c}\text { Moisture content, } \\
\%\end{array}$ & $\begin{array}{c}\text { Smoke temperature, } \\
{ }^{\circ} \mathrm{C}\end{array}$ & $\begin{array}{c}\mathrm{CO}_{2} \\
\%\end{array}$ & $\begin{array}{c}\mathrm{CO} \\
\mathrm{ppm}\end{array}$ & $\begin{array}{c}\mathrm{NO}_{\mathrm{x}} \\
\mathrm{ppm}\end{array}$ & $\begin{array}{c}\mathrm{C}_{\mathrm{x}} \mathrm{H}_{\mathrm{y}} \\
\mathrm{ppm}\end{array}$ \\
\hline Elephant grass & 8.4 & 193.4 & 5.2 & 2294.7 & 216.1 & 61.0 \\
\hline Sida & 9.6 & 215.2 & 7.9 & 1252.5 & 215.1 & 24.0 \\
\hline Reed canary grass & 6.7 & 222.9 & 7.4 & 905.2 & 176.2 & 56.2 \\
\hline
\end{tabular}

Based on the results, the general tendency in the burning process was that the emissions of all harmful gases was reduced as the energy plant finished burning and burning intensity was reduced.

The average values of determined harmful emissions from burning granules of unconventional herbaceous energy plants are presented in Table 4.

When burning various unconventional herbaceous energy plants, the largest concentration of carbon monoxide (CO) was determined when burning elephant grass (2294.7 ppm), and the smallest concentration of $\mathrm{CO}$ was detected when burning reed canary grass (905.2 ppm). No emission of sulphur dioxide $\mathrm{SO}_{2}$ was detected.

Small emissions of carbon dioxide $\left(\mathrm{CO}_{2}\right)$ were noticed when burning biofuel pellets. The most carbon dioxide was determined when burning sida (7.9\%), and the smallest quantity of $\mathrm{CO}_{2}$ was obtained when burning elephant grass $(5.2 \%)$.

Small values of unburnt hydrocarbons, $\mathrm{C}_{\mathrm{x}} \mathrm{H}_{\mathrm{y}}$, were detected, which varied from 24.0 to $61.0 \mathrm{ppm}$. Scientists from Poland evaluated hydrocarbons concentration from wood pellets and it was $421 \mathrm{ppm}$ [22].

The data of burning granules of unconventional herbaceous energy plants and evaluation of emissions of nitrogen oxides, $\mathrm{NO}_{\mathrm{x}}$, show that emissions did not exceed permissible values. The determined nitrogen oxide emissions differed insignificantly, varying from $176.2 \mathrm{ppm}$ (reed canary grass) to $216.1 \mathrm{ppm}$ (elephant grass) (Table 4). The researchers from USA and Poland reported that $\mathrm{NO}_{\mathrm{x}}$ emissions from wood biomass were not significantly less and reached $170 \mathrm{mg} \mathrm{m}^{-3}$ concentration [23].

Analysing the results obtained from the burning of unconventional plant pellets and their emissions, we can recommend three plants for growing as unconventional energy plants in Lithuania. However, additional energy expenses are needed for mass drying. Sufficient qualitative and effective burning and minimal emission of pollutants to the environment were achieved.

According to the research results of other researchers, $\mathrm{CO}$ concentration of straw pellets is $6.4 \pm 5.0 \mathrm{~g} / \mathrm{kg}$ and wood pellets, $1.3 \pm 1.9 \mathrm{~g} / \mathrm{kg}$. $\mathrm{NO}_{\mathrm{x}}$ concentration was $3.6 \pm 0.8 \mathrm{~g} / \mathrm{kg}$ and $1.4 \pm 0.2 \mathrm{~g} / \mathrm{kg}$ respectively [24].

Other researchers estimated that the concentration $\mathrm{CO}$ of peat was $140 \pm 27 \mathrm{mg} / \mathrm{MJ}$ and $\mathrm{NO}_{\mathrm{x}}$ concentration was $225 \pm 29 \mathrm{mg} / \mathrm{MJ}$ [25].
Scientists of Finland investigated the biofuel of wood - reed canary grass mixture with amounts of 78\% and $22 \%$. CO concentration was $9.6 \pm 3.1 \mathrm{mg} / \mathrm{MJ}$, and $\mathrm{NO}_{\mathrm{x}}$ concentration reached $212 \pm 17 \mathrm{mg} / \mathrm{MJ}$ [26].

Researchers from the Czech Republic were estimating $\mathrm{CO}, \mathrm{NO}_{x}$ and $\mathrm{HCl}$ concentrations of reed canary grass, giant knotweed and elephant grass. They determined that burned reed canary grass emitted $746 \mathrm{mg} / \mathrm{m}^{3}$ of CO, $248 \mathrm{mg} / \mathrm{m}^{3}$ of $\mathrm{NO}_{\mathrm{x}}$ and $198 \mathrm{mg} / \mathrm{m}^{3}$ of $\mathrm{HCl}$. Giant knotweed emitted 249, 300 and $238 \mathrm{mg} / \mathrm{m}^{3}$, and elephant grass 543, 167 and $133 \mathrm{mg} / \mathrm{m}^{3}$ respectively [27].

Other researchers investigated giant knotweed briquettes. There were determined $\mathrm{CO}, \mathrm{NO}_{\mathrm{x}}$ and $\mathrm{HCl}$ concentrations. $\mathrm{CO}$ concentration has big value $3088.6 \mathrm{mg} / \mathrm{m}^{3}, \quad \mathrm{NO}_{\mathrm{x}}-194.95 \mathrm{mg} / \mathrm{m}^{3}$ and $\mathrm{HCl}-$ $157.69 \mathrm{mg} / \mathrm{m}^{3}$. Wood briquettes were burned and also got such results: $\mathrm{CO}-2313.6 \mathrm{mg} / \mathrm{m}^{3}, \mathrm{NO}_{\mathrm{x}}-$ $48.25 \mathrm{mg} / \mathrm{m}^{3}$ and $\mathrm{HCl}-39.03 \mathrm{mg} / \mathrm{m}^{3}$. We can see that wood biofuel is less harmful than giant knotweed [28]. Also, they investigated giant knotweed pellets and determined $\mathrm{CO}-928,9 \mathrm{mg} / \mathrm{m}^{3}$ and $\mathrm{NO}_{\mathrm{x}}-297,0 \mathrm{mg} / \mathrm{m}^{3}$ concentrations [29].

Latvian scientists determined quality indicators of reed canary grass in spring and autumn yields and found that moisture content of spring harvest was $9.85 \%$ and the autumn harvest was about twice as high at $17 \%$ [30].

Researchers from Romania investigated the thermal properties of Miscanthus pellets, and determined that the calorific value of these pellets was very high and reached a value of $17.6 \mathrm{MJ} / \mathrm{kg}$ [31].

The research experience of the Lithuanian Institute of Agriculture in Dotnuva for growing of Miscanthus shows that this grass can be used for biofuel production. Among other herbaceous plants, Miscanthus has some advantages. First of all, it needs very few agrochemicals, because they overrun weeds by themselves. They do not need fertilizers because before winter it stores nutrients in the rhizomes, and also can get nutrients from fallen leaves. The yield is 12-18 tons per hectare. They are suitable for cutting in late winter or early in spring when moisture content reaches $15-20 \%$. [32]

All mentioned scientists proved that reed canary grass, sida and Miscanthus characterize high-quality features and can be used as solid biofuel beside wood and straw pellets or briquettes. The main advantage that involves burning pellets is that gas concentration fits the requirements of harmful gas emissions. Similar research 
Table 5. Prime cost of granulated biofuel.

\begin{tabular}{|c|c|c|c|c|c|}
\hline $\begin{array}{c}\text { Biofuel } \\
\text { pellets }\end{array}$ & $\begin{array}{c}\text { Calorific value, } \\
\mathrm{MJ} \mathrm{kg}^{-1}\end{array}$ & $\begin{array}{c}\text { Pellet cost, } \\
\text { EUR/kg }\end{array}$ & 1 MJ cost, EUR & $\begin{array}{c}1 \mathrm{kWh} \text { cost, } \\
\text { EUR }\end{array}$ & $\begin{array}{c}\text { Coefficient of boiler } \\
\text { efficiency }\end{array}$ \\
\hline Wood & 18.0 & $0.09-0.10$ & 0.005 & 0.014 & 0.85 \\
\hline Straw & 16.3 & 0.11 & 0.006 & 0.016 & 0.85 \\
\hline Elephant grass & 17.8 & 0.13 & 0.006 & 0.017 & 0.85 \\
\hline Sida & 17.4 & 0.13 & 0.006 & 0.017 & 0.85 \\
\hline Reed canary grass & 17.4 & 0.13 & 0.006 & 0.018 & 0.85 \\
\hline
\end{tabular}

results were obtained by investigating properties and environmental impacts of various energy plants grown in Lithuanian climatic conditions.

\section{Economic Evaluation of Herbaceous Pellet Preparation and Use for Burning}

To calculate the prime cost of granulated biofuel, the equipment prices and other prices were accepted according to 2016 prices. As prices constantly increase, this prime cost is approximate, and is provided for the sake of orientation. We determined that for granule production, if biomass was not artificially dried in a dryer, the prime cost of this fuel was approximately $0.12 \mathrm{EUR} / \mathrm{kg}$. Grass drying before granulation increased the prime cost by $0.13 \mathrm{EUR} / \mathrm{kg}$ (Table 5 ).

The highest energy coefficient of efficiency and the smallest fuel prime cost were obtained when artificial drying was not required. As the moisture of granulated biomass should not exceed $13-14 \%$, the collection time for energetic grass should be selected when plant water content is lowest. Having evaluated the caloricity of biofuel granules, and accepting that coefficient of boiler efficiency (for all calculated cases) was 0.85 , the primecost per energy unit (MJ and $\mathrm{kWh}$ ) of granulated biofuel was calculated (Table 5).

The obtained calculation results enabled us to state that prime-cost of warmth unit of wooden granules is $20-30 \%$ lower than that of other unconventional herbaceous plants and granules of straw.

\section{Conclusions}

1. Wood biomass fuel could be replaced by various unconventional herbaceous energetic plants, including reed canary grass (Phalaris arundinacea), elephant grass (Miscanthus giganteus) and sida (Sida hermaphrodita Rusby). Harvest and chopping technologies for these plants are identical to technologies for forage preparation using common cutting, chopping and pressing techniques.

2. The physical-mechanical characteristics (moisture, density, filling angles) were determined for chopping using a drum chopper and milling using a hammer mill for the three unconventional grasses. The largest chaff fraction was found in the sieve with $8-\mathrm{mm}$ diameter holes (52.0 to $62.7 \%$ ), and the largest mill fraction was found in the sieve with 0.5 -and $0.63-\mathrm{mm}$ diameter holes (37.6 to $46.4 \%$ ).

3. The investigated plant pellet of highest density was determined for reed canary grass pellets $\left(1035.1 \pm 63.9 \mathrm{~kg} \mathrm{~m}^{-3} \mathrm{DM}\right)$, and the lowest density was for elephant grass pellets $\left(653.6 \pm 67.1 \mathrm{~kg} \mathrm{~m}^{-3} \mathrm{DM}\right)$. Pellet moisture content was sufficiently low and varied from $6.7 \%$ to $9.6 \%$.

4. The emission of harmful gases was measured when burning the unconventional energy plants. The highest concentration of carbon monoxide (CO) was detected when burning elephant grass (2294.7 ppm), and the smallest concentration of CO was observed when burning reed canary grass (905.2 ppm). The highest carbon dioxide was measured when burning sida (7.9\%), and the lowest when burning elephant grass $(5.2 \%)$. Emissions of nitrogen oxide differed insignificantly, varying only from $176.2 \mathrm{ppm}$ (Phalaris arundinacea) to $216.1 \mathrm{ppm}$ (Miscanthus)

5. It was calculated that producing granules when biomass was not dried artificially in a dryer, a prime cost of granules reached $0.12 \mathrm{EUR} / \mathrm{kg}$. When drying energy grasses in a dryer using a dispergation method, the primary cost will increase to $0.13 \mathrm{EUR} / \mathrm{kg}$.

\section{Acknowledgements}

Research investigations and main research results have been obtained in support from a project of the Lithuanian Ministry of Agriculture.

\section{Conflict of Interest}

The authors declare no conflict of interest.

\section{References}

1. STOLARSKI M.J., KRZYZANIAK M., WARMINSKI K., TWORKOWSKI J., SZCZUKOWSKI S. Willow Biomass Energy Generation Efficiency and Greenhouse 
Gas Reduction Potential. Pol. J. Environ. Stud. 24 (6), 2627, 2015.

2. ČERNIAUSKIENE Ž., RAILA A.J., ZVICEVIČIUS E., KADŽIULIENĖ Ž., TILVIKIENĖ V. Analysis of Artemisia dubia Wall. growth, preparation for biofuel and thermal conversion properties. Renewable Energy, 118, 468, 2018.

3. ZVICEVIČIUS E., RAILA A., ČIPLIENĖ A., ČERNIAUSKIENĖ Ž., KADŽIULIENĖ Ž., TILVIKIENE V. Effects of moisture and pressure on densification process of raw material from Artemisia dubia Wall. Renewable Energy, 119, 185, 2018.

4. IGLINSKI B., IGLIN A., KUJAWSKI W., BUCZKOWSKI R., CICHOSZ M. Bioenergy in Poland. Renew Sustain Energy Reviews, 15, 2999, 2011.

5. ŽALTAUSKAS A., JASINSKAS A., KRYŽEVIČIENE் A. Analysis of the Suitability Tall-Growing Plants for Cultivation and Use as a Fuel. Perspective Sustainable Technological Processes in Agricultural Engineering: proceedings of the International Conference, LIAE, Raudondvaris, 20-21 September, 155, 2001.

6. CARVALHO ROCHAA J.U., CAMPOLINA MACHADOB J., SOUZA CARNEIROA P.C., COSTA CARNEIROB J., VILELA RESENDEC M.D., VANDER PEREIRAB A., SOUZA CARNEIROA JE. Elephant grass ecotypes for bioenergy production via direct combustion of biomass. Industr Crops Products, 95, 27, 2017.

7. CLIFTON-BROWN J., LEWANDOWSKI I., ANDERSSON B. Performance of 15 Miscanthus Genotypes at Five in Europe. Agronomy Journal, 93, 1014, 2001.

8. LEWANDOWSKI I., JONATHAN MO., SCURLOCK JMO., LINDVALL E., CHRISTOUD M. The development and current status of perennial rhizomatous grasses as energy crops in the US and Europe. Biomass Bioenergy, 25, 335, 2003.

9. KRYŽEVIČIENĖ A., ŽALTAUSKAS A., JASINSKAS A. Cultivation and utilization of the perennial grasses as biofuel. Agricultural Sciences, 1, 40, 2005 [In Lithuanian].

10. CANNELL MR. Carbon sequestration and biomass energy offset: theoretical, potential and achievable capacities globally, in Europe and the UK. Biomass Bioenergy, 24, 97, 2003

11. JASINSKAS A. Estimation of Physical-Mechanical Properties of Tall Growing Bioenergy Plants. Progressive Eco-Friendly Technological Processes in Agricultural Engineering: proceedings of the International Conference LIAE, Raudondvaris, 19-20 September, 187, 2002.

12. VENTURI P., VENTURI G. Analysis of energy comparison for crops in European agricultural systems. Biomass Bioenergy, 25, 235, 2003.

13. ŠIAUDINIS G., JASINSKAS A., ŠLEPETIENE A., KARČIAUSKIENE D. The evaluation of biomass and energy productivity of common mugwort (Artemisia vulgaris L.) and cup plant (Silphium perfoliatum L.) in Albeluvisol. Žemdirbystė-Agriculture, 99(4), 357, 2012.

14. NAVADVORSKYTE் J. Herbaceous plant utilization for solid biofuel. Research work, VMU, Kaunas, 60, 2013.

15. BORKOWSKA H., MOLAS R. Two extremely different crops, Salix and Sida, as sources of renewable bioenergy. Biomass Bioenergy, 36, 234, 2012.

16. ŠIAUDINIS G., JASINSKAS A., ŠARAUSKIS E., STEPONAVIČIUS D., KARČIAUSKIENE D., LIAUDANSKIENE I. The assessment of Virginia mallow
(Sida hermaphrodita Rusby) and cup plant (Silphium perfoliatum L.) productivity, physicoemechanical properties and energy expenses. Energy, 93 (1), 606, 2015.

17. DJATKOV D., VISKOVIC M., GOLUB M., MARTINOV M. Corn cob pellets as a fuel in Serbia: opportunities and constraints. Symposium "Actual Tasks on Agricultural Engineering", Opatija, Croatia, 2017.

18. ASINSKAS A., SIMONAVIČIŪTĖ R., ŠIAUDINIS G., LIAUDANSKIENE I., ANTANAITIS Š., ARAK M., OLT J. The assessment of common mugwort (Artemisia vulgaris L.) and cup plant (Silphium perfolatium L.) productivity and technhological preparation for solid biofuel. Zemdirbyste-Agriculture, 101 (1), 19, 2014.

19. CEN/TC 14774-1:2005. Solid biofuels - Methods for the determination of moisture content - Oven dry method Part 1: Total moisture - Reference method. 2005.

20. R., MAKAREVIČIENE $\quad$ V., ŠARŪNAITE $\quad$ L., TILVIKIENE V., ŠLEPETYS J. Miscanthus biomass quality composition and methods of feedstock preparation for conversion into synthetic diesel fuel. ZemdirbysteAgriculture, 101 (1), 27, 2014.

21. JASINSKAS A., SAKALAUSKAS A., ŠARAUSKIS E., VAICIUKEVIČIUS E., KALINAUSKAITĖ S. Investigation of boiler efficiency and harmful emissions while burning of plant biomass briquettes. J Food Agricult Environment. Helsinki: WFL Publisher, 10 (3\&4), 1124, 2012.

22. SZYSLAK-BARGLOWICZ J., ZAJAC G., SLOWIK T. Hydrocarbon emissions during biomass combustion. Pol. J. Environ.Stud. 24 (3), 1349, 2015.

23. HIGGINS B., YAN L., GADALLA H., MEIER J., FAREID T., LIU G., MILEWICZ M., REPCZYNSKI A., RYDING M., BLASIAK W. Biomass co-firing retrofit with ROFA for $\mathrm{NO}_{\mathrm{x}}$ reduction. Pol. J. Environ. Stud. 19(6), 1185, 2010.

24. KRUGLY E., MARTUZEVIČIUS D., PUIDA E., BUINEVIČIUS K., STASIULAITIENE I., RADŽIŪNIENĖ I., MINIKAUSKAS A., KLIUČININKAS L. Characterization of gaseous- and particle-phase emissions from the combustion of biomass-residue-derived fuels in a small residential boiler. Energy and fuels, 28, 5057, 2014.

25. SIPPULA O., LAMBERG H., LESKINEN J., TISSARI J., JOKINIEMI J. Emissions and ash behavior in a $500 \mathrm{~kW}$ pellet boiler operated with various blends of woody biomass and peat. Fuel, 202, 144, 2017.

26. KORTELAINEN M., JOKINIEMI J., NUUTINEN I., TORVELA T., LAMBERG H., KARHUNEN T., TISSARI J., SIPPULA O. Ash behaviour and emission formation in a small-scale reciprocatinggrate combustion reactor operated with wood chips, reed canary grass and barley straw. Fuel, 143, 80, 2015.

27. HUTLA P., JEVIČ P., MAZANCOVA J., PLIŠTIL D. Emission from energy herbs combustion. Research in agricultural engineering, 51 (1), 28, 2005.

28. STRAŠIL Z., KARA J. Study of knotweed (Reynoutria) as possible phytomass resource for energy and industrial utilization. Research in agricultural engineering, 56, 161, 2010.

29. MALATAK J., PASSIAN L. Heat-emission analysis of small combustion equipments for biomass. Research in agricultural engineering, 57, 37, 2011.

30. PLATACE R., ADAMOVICS A., GULBE I. Evaluation of factors influencing calorific value of reed canary grass spring and autumn yield. Engineering for rural 
development, Proceedings of the $12^{\text {th }}$ international scientific conference. 522, 2013.

31. MARIS S., NENU P.F., MARIS S.A., SLAVICI T. Estimating the calorific value of pellets from different blends of biomass. Symposium "Actual Tasks on Agricultural Engineering", Opatija, Croatia, 2017.

32. PATASIUS A. Suggestions for growing Miscanthus in Lithuania. Forests. 12, 2011. 